\title{
Effect of bottom flange cleat on integrated precast slab and column panel using cold-formed steel
}

\author{
Sutanto Muliawan ${ }^{1}$, Anis Saggaff ${ }^{1}$, Mahmood Bin Md Tahir ${ }^{2}$, Saloma $^{1^{*}}$, Muhammad Firdaus ${ }^{3}$, and \\ KM Aminuddin ${ }^{1}$ \\ Civil Engineering Department, Faculty of Engineering, Universitas Sriwijaya, Inderalaya, Indonesia ${ }^{1}$ \\ Institute for Smart Infrastructure and Innovative Construction (ISIIC), Construction Research Centre (CRC), School \\ of Civil Engineering, Universiti Teknologi Malaysia, Johor Bahru, Malaysia ${ }^{2}$ \\ Civil Engineering Department, Faculty of Engineering, Universitas Persatuan Guru Republik Indonesia, Palembang, \\ Indonesia $^{3}$
}

Received: 07-February-2021; Revised: 22-March-2021; Accepted: 25-March-2021

(C)2021 Sutanto Muliawan et al. This is an open access article distributed under the Creative Commons Attribution (CC BY) License, which permits unrestricted use, distribution, and reproduction in any medium, provided the original work is properly cited.

\begin{abstract}
The use of cold-formed steel currently develops very fast. It is due to its advantages such as durability, stability, noncombustibility, sustainability, and cost-effectively. On the other hand, its disadvantages are difficult to connect, low fire resistance, residual stress on the cross-section that affects buckling resistance. In the previous research, to overcome the lack of buckling resistance in cold-formed steel, the composite connection is proposed. A recent study about cold-formed steel connection is divided into non-composite and composite research. The result of composite research has a higher moment capacity than non-composite. Most of the composite research is focused on beam and column with the concrete slab above the beam. In the current study, a T-shaped of gusset plates is used as a joint connector. This study aims to investigate the effect of the bottom flange cleat on the joint capacity. The slab panel's material is a Lipped Channel Section with the size of 12524 as the frames and reinforcements. The grade of cold-formed steel is fy $=530 \mathrm{MPa}$ and fu= $590 \mathrm{MPa}$, while the T-shaped plate connector's strength is $\mathrm{S355}$. The bolt used has a diameter of $10 \mathrm{~mm}, \mathrm{fy}=800 \mathrm{MPa}$. The flange cleats used is $\mathbf{L} 100 \times 100 \times 10 \times 80$. The parametric study was conducted based on Eurocode 3 . The connection with the additional bottom flange cleat has a higher moment resistance than without the flange cleat. The additional bottom cleat's influence is that the moment resistance increased the moment resistance from $17.11 \mathrm{kNm}$ to $23.32 \mathrm{kNm}$. The predicted failure mode of the connection could be the failure that occurred at the top side of the cold-formed section of the slab due to the bending.
\end{abstract}

Keywords

Cold-formed steel connection, Bottom flange cleat, Integrated precast slab, Joint flexural resistance, T-shaped plate connector.

\section{Introduction}

Cold-Formed Steel (CFS) is lightweight steel produced by forming the thin plate in cool condition. It became widely used for any purpose of household furniture and light construction elements from the middle of the twentieth century. CFS could be used as purlin, roof cover, steel truss, wall panel, composite deck slab, and structural framing. One of the disadvantages is the buckling problem which reduces the maximum load. The development of technology leads to the massive product of CFS. CFS became more popular and well-accepted in any region in the world [1].

*Author for correspondence 462
There are still very few studies on the composite connection of cold-formed steel [2-5]. Throughout the research, the concrete is considered as normal concrete with $\mathrm{fc}^{\prime}=30 \mathrm{MPa}$ until $\mathrm{fc}{ }^{\prime}=43 \mathrm{Mpa}$, with the result of those studies were moment-rotation, failure mode, and load deflection. The type of connection is a rectangular gusset plate $[3,4]$ and a haunched gusset plate with seat angles $[2,5]$.

The non-composite research about cold-formed steel connection is about the bolt connection with various gusset plates [6-10]. The type of connection for the non-composite is rectangular gusset plate [6], rectangular gusset plate with flange cleat [7], haunched gusset plate [8], welded connection [9], and T-Shaped gusset plate [10]. 
Both composite and non-composite had an addition to the flange-cleat connection $[2,5,7]$. The flangecleat connection is related to fast installation and lack of expensive welding processes. The flange cleats are often used to reinforce the joint in the existing structure. The investigation of concrete slab combines with cold-formed steel as the primary beam was conducted [11-15]; the purpose of those study is to find out the behaviour of the cold-formed component within the slab shear connector configuration $[11,12,15]$ and beam variation [13, 14].

Based on recent research, the beam-column composite connection shown that the beam section is located outside the slab part. In this study, there is a difference in beam location with the previous research [2-5]. The beam is located inside the slab part, and there is no study about the encase beamcolumn connection before. The encase beam does not require a space outside the slab part. Therefore, a wider space below the concrete slab can be produced. The precast panel slab with a $1 \times 1$-meter size using a cold-formed steel section will be connected by a Tshape connection to the precast column panel with a $1 \times 3$-meter size of the CFS section. This study aims to compare the maximum moment capacity of the previous study without the bottom flange cleat and with the additional bottom flange cleat. This paper's method is limited by a parametric study based on BS EN 1993-1-1 and BS EN 1993-1-8.

It is hoped that the result of this study will be useful for the researchers who investigate the same slab panel with or without integration with concrete.

\section{Literature review}

Generally, the research on bare steel cold-formed steel (CFS) is to obtain the best performance of the connection and should be simple and easy to install. The use of CFS was growing rapidly and leads to the main components of the structure, however, without being balanced with design standards and because of the lack of related literature. The established code of standards recently still focused on hot-rolled steel joints. Therefore, several CFS studies have been carried out through parametric and experimental approaches by applying a monotonic loading at the end of the beam so that the joint's moment of rotation and stiffness can be generated. Furthermore, connection behaviour can also be investigated.

Aminuddin et al. [6] examined the beam to column joints of bare build up cold-formed steel connected by rectangular gusset plates $10 \mathrm{~mm}$ thick, experimentally and analytically. The beam depth varies from $200 \mathrm{~mm}, 250 \mathrm{~mm}$, and $300 \mathrm{~mm}$, and the same column size $($ depth $=300 \mathrm{~mm})$. The experimental results show that the beam depth should be limited to obtain ductile joint behaviour. The study was continued with the same type of connection, but with the addition of top angle and seat angle with a thickness of $6 \mathrm{~mm}$ Aminuddin et al. [7]. The comparison of the two specimens shows that the influence of the top and seat angle could increase the moment capacity and stiffness of the connection.

Firdaus et al. [8] continued the research on noncomposite joints that Aminuddin had done. The beam and column dimensions are the same as previous studies [6,7], but the haunched gusset plate was selected. This shape was chosen to avoid premature buckling of the gusset plate. A total of 6 specimens were carried out experimentally, three specimens used gusset plates only, and the remaining specimens were reinforced with top angle, seat angle and web angle. The experimental results also show an increase in moment capacity by $20 \%$ and $30 \%$ for stiffness. It means that the addition of seat angle components can be used as a recommendation to increase the joint's strength without having to dismantle the structure as a whole.

The weakness of bare cold-formed steel tends to lateral torsion due to the thin plates' behaviour, which can be overcome by the integration of CFS beams and concrete slabs as part of the composite. However, the knowledge of lightweight steel composite joints is still limited. The intensive research on the lightweight steel composite joints with gusset plates has been carried out experimentally and analytically by Firdaus et al. [16]. Furthermore, Firdaus et al. [17] proposed tools software to predict connection capacity because it requires many calculations, iterative, trial, and error. A total of six specimens were studied with dimensions of beam DLC200,250, 300 , respectively, and column with DLC300. The two types of connection were investigated, the first type using gusset plates and web stiffener, and the second type is the same as the first type but with the addition of a seat angle placed on the bottom beam flange. The experimental results show that increasing the seat angle could increase $8 \%$ for the moment resistance and $17 \%$ for the joint's stiffness. However, the presence of a seat angle makes the connection lead to full-strength joint behaviour. 
Although several studies have shown the potential of CFS as an alternative material, applying that material as part of the main structure has not yet been established. Lawan et al. [18] was argued in their paper that CFS could be used as the primary beam, but it is limited to small and medium buildings. This statement is based on his research on composite beams, combined with shear connectors from bolts with sizes M12, M14, and M16, beam dimensions with DLC250 and DLC300 [14]. The Four-point bending test procedure was conducted, and the flexural capacity of the experiment is considered sufficient to be categorized as the primary beam.

Furthermore, Salih et al. [15] was investigated a lightweight steel composite beam. The beam configuration was installed through-bolts to connect the lipped channel back to back (I-shape) and toe to toe (box-shape). This study demonstrated that CFS sections could be fabricated easily because of the lightweight material. Self-Compacted Concrete (SCC) was used to fill material for concrete beams and slabs. Composite behaviour is achieved by attaching a shear connector made of U-shape rebar. The bending test shows that the I-shape profile could provide $24.2 \%$ more capacity than the box-shape, even though the cross-section and volume of the material used are identical. It could be due to the higher moment of inertia of the I-shape, which shows that back-to-back lipped channel could provide economic savings.

Qiao et al. [19] has investigated the research on concrete slabs with CFS, where the CFS was cast in the concrete slab. This method directly eliminates local buckling of the thin plate due to concrete surrounding the CFS profile. Also, the volume of concrete will be reduced due to the existence of CFS in the slab. The author claims that this is a new method of utilizing lightweight steel as part of the structural member. The experimental and Finite element tests were carried out with two specimens, where CS-1 used 4 CFS and CS-2 used 3 CFS which were installed on the plate. CS-1 provides superior in terms of strength and ductility to CS-2. This is the confirmation of a positive contribution from CFS elements as a substitute for conventional rebars. The parametric studies regarding the CFS slab connection to the column have been studied by Muliawan et al. [10]. It is based on the fact that the calculation procedure not available. In addition, the application of composite slabs as part of the building can only be used if there is an adequate connection to transfer the slab load to the column. The dimensions of CFS with 12524 was selected as beams and columns. The gusset plate with $4 \mathrm{~mm}$ thick is used as a connecting medium between beams and columns by applying various bolts M10, M12, M14, and M16. From the analysis, it can be concluded that M10 and M12 bolts can be applied to these joints. While M16 bolts can only be used for beams with dimensions more than CFS12524 because of the unfulfilled range of validity that has been set in EC3.

\section{Methods}

In this study, there are two kinds of specimens. IJT-1 for specimen without flange cleat and IJT-2 for specimen with flange cleat. The IJT-1 specimen is shown in Figure 1, and the IJT-02 specimen configuration in Figure 2. The full-scale sample of this current study is shown in Figure 3. The column height is $3000 \mathrm{~mm}$, and the width of $1000 \mathrm{~mm}$. The column is made by CFS with Lipped Channel (LC) 12524 profile. The length of the slab is $1000 \mathrm{~mm}$ and $1000 \mathrm{~mm}$ in width. The Double Lipped Channel (DLC) 12524 CFS profile is placed in the middle of the column and the slab. For CFS profile design strength is Fy = $530 \mathrm{MPa}, \mathrm{Fu}=590 \mathrm{MPa}$.

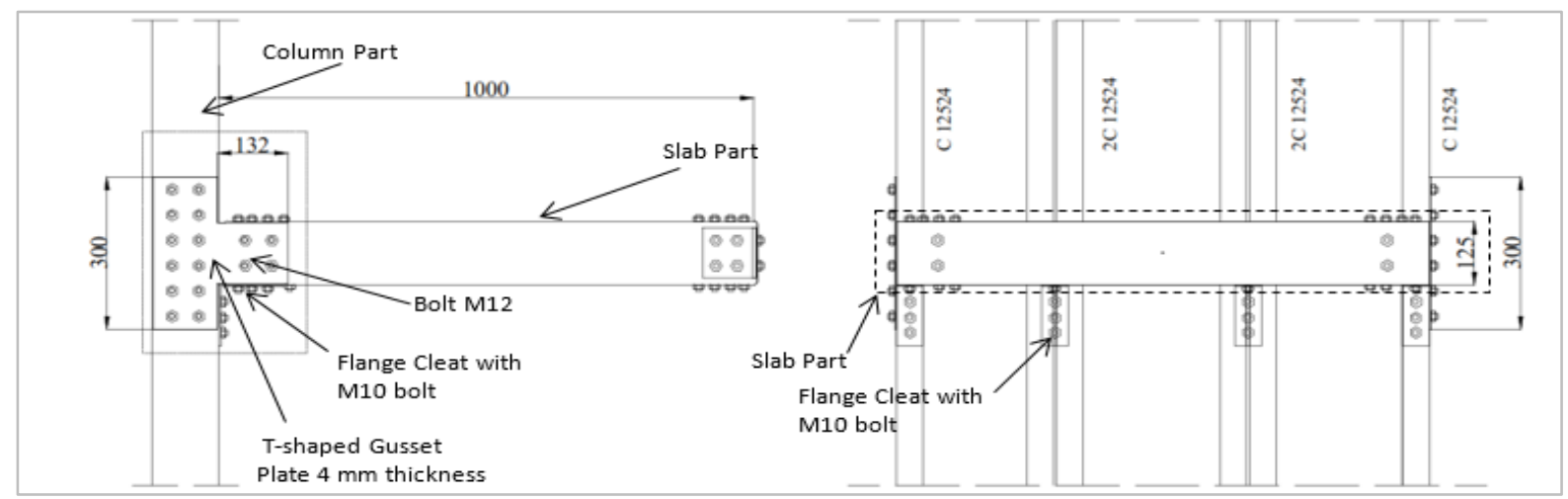

Figure 1 IJT-01 Specimen in right and front side view 


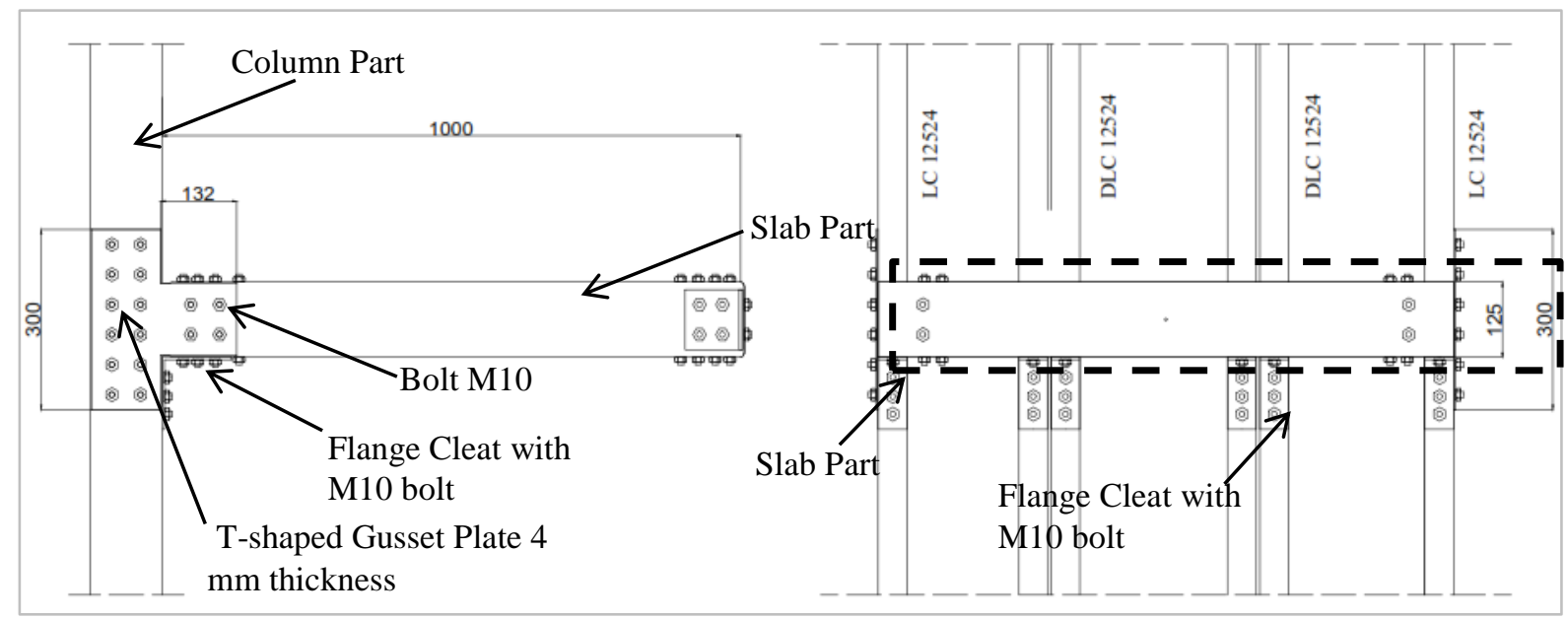

Figure 2 IJT-02 Specimen in the right and front side view

There is a bolt connection with a T-Shaped gusset plate to connect the slab and column. The bolts are designed based on BS EN 1-8:2005 [20]. All bolts grade are 8.8 , with the ultimate strength $\left(\mathrm{F}_{\mathrm{u}}\right)$ is 800 $\mathrm{MPa}$. The bolts stress area $\left(\mathrm{A}_{\mathrm{s}}\right)$ is $58.0 \mathrm{~mm}^{2}$. The Tshaped plate had a thickness of $4 \mathrm{~mm}$ with S355 grade $\left(\mathrm{F}_{\mathrm{y}}=355 \mathrm{MPa}, \mathrm{F}_{\mathrm{u}}=510 \mathrm{MPa}\right)$ based on BS EN 1-1: 2005[21]. The T-Shape connection is shown in Figure 4.

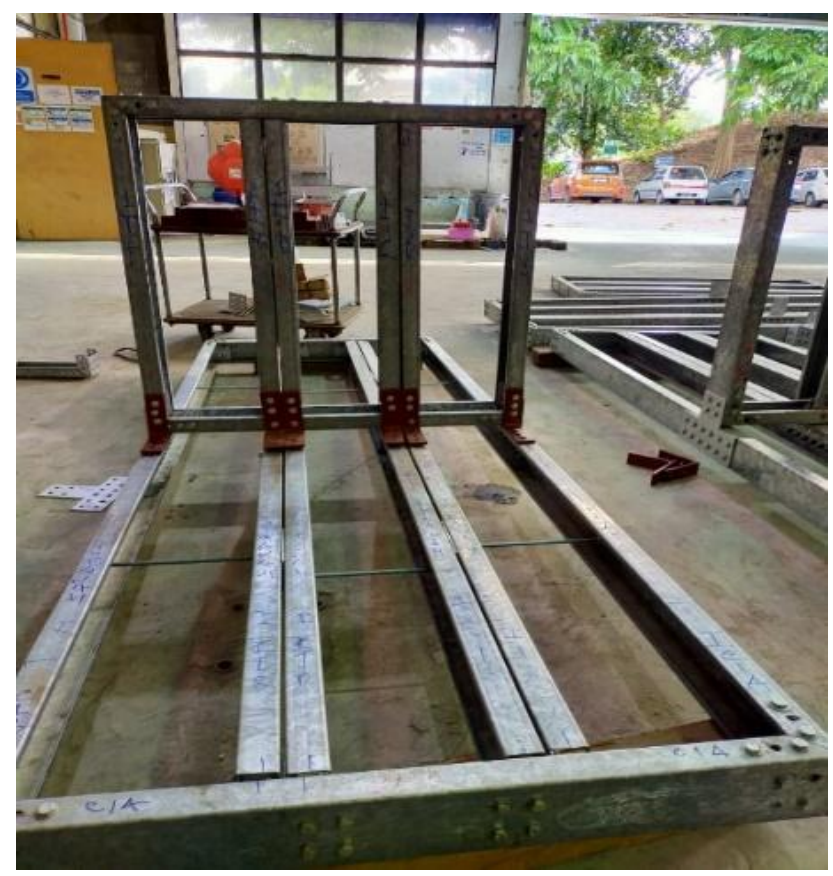

Figure 3 The actual specimen

The channel lips section could be seen in Figure 5. The channel lips profile used in this research is LC 12524. The detail is the thickness (t) $2.4 \mathrm{~mm}$, height (h) $125 \mathrm{~mm}$, broad (b) $50 \mathrm{~mm}$, and lips (c) $15 \mathrm{~mm}$. There is a flange cleat with grade $\mathrm{S} 355$, fy $=275$ $\mathrm{MPa}, \mathrm{fu}=430 \mathrm{MPa}$. The bottom flange cleat component is shown in Figure 6.

For bolt spacing configuration on the gusset plate is based on BS EN 1-8:2005 [20], there is edge distance between the bolt and the edge of the plate. The steel specimen is exposed to the weather and other corrosive influences. From BS EN 1-8:2005 [20], M10 bolts the hole diameter $\left(\mathrm{d}_{0}\right)$ is $11 \mathrm{~mm}$. Based on BS EN 1-8:2005, the range validity of bolts as follows:

Minimum $\mathrm{e}_{\mathrm{f}}=1.2 \mathrm{~d}_{0}$

Maximum $\mathrm{e}_{\mathrm{f}}=4(\mathrm{t})+40 \mathrm{~mm}$

$\mathrm{d}_{0}$ is the hole diameter, and $\mathrm{t}$ is the thickness of the thinner outer connected part.

The minimum horizontal spacing between the bolt $\left(\mathrm{p}_{1}\right)$ had to be calculation below.

Minimum $\mathrm{e}_{\mathrm{s}}=2,2 \mathrm{~d}_{0}$

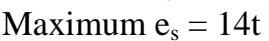

Bolt configuration on the vertical direction $\left(\mathrm{p}_{2}\right)$ is calculated below.

Minimum $\mathrm{e}_{\mathrm{v}}=2,4 \mathrm{~d}_{0}$

Maximum $\mathrm{e}_{\mathrm{v}}=14 \mathrm{t}$

The analytical method is based on the component method. There is a flowchart of the study shown in Figure 7. First, collecting the component data such as a bolt, gusset plate, angle clamp, cold-formed steel, and bottom flange cleat data. Then, do the parametric calculation based on BS EN 1993-1-8:2005. The IJT01 and IJT-02 specimens are being calculated in this study. Then, after the calculation has finished for both specimen, there is a result comparison between IJT-01 and IJT-02. 

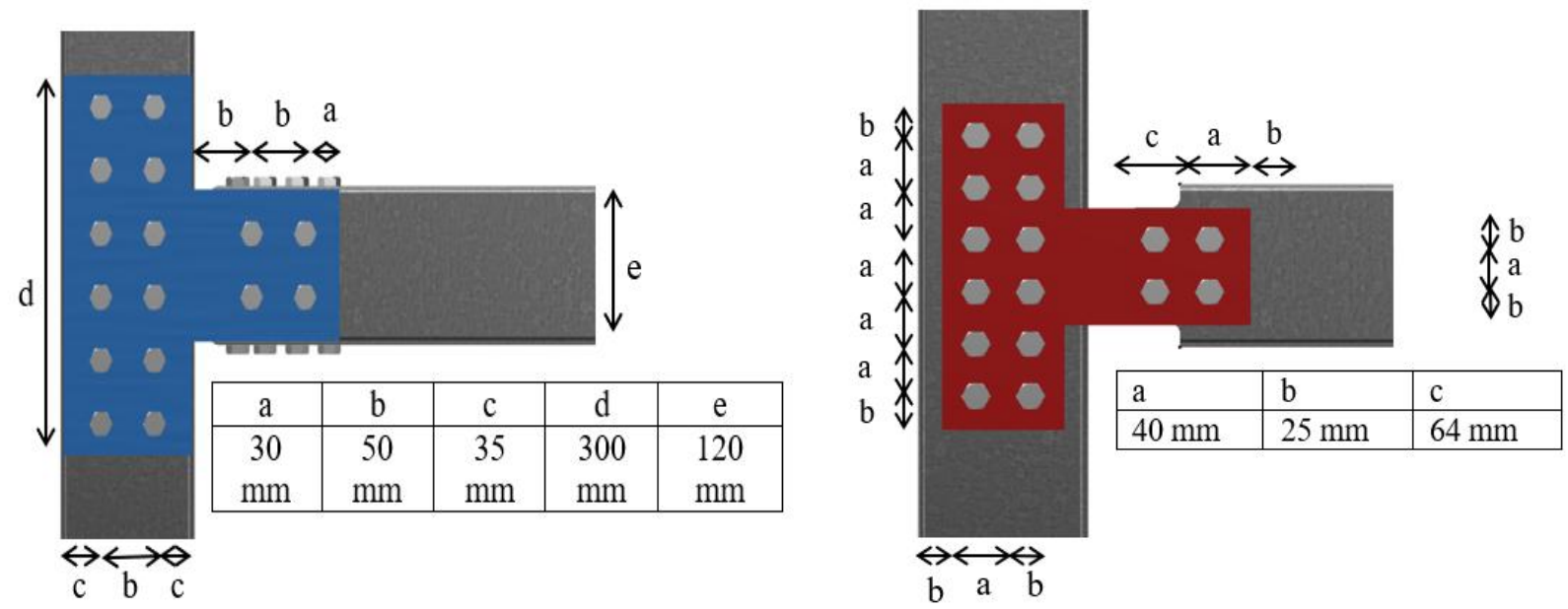

Figure 4 T-Shape plate connection

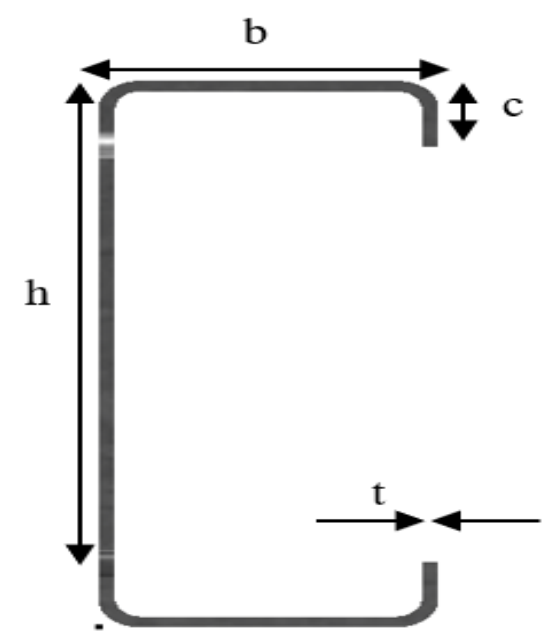

Figure 5 Cold-formed steel section

According to BS EN 1993-1-8:2005, there is a shear resistance of bolt calculation in equation 18 . The bearing resistance in equation 19.

$\mathrm{F}_{\mathrm{v}, \mathrm{Rd}}=\frac{\alpha_{v} f_{u b} A_{S}}{\gamma_{M 2}}$

Where $\alpha_{\mathrm{v}}$ is 0.6 for bolt grade 8.8 ; $\mathrm{f}_{\mathrm{ub}}$ is the ultimate strength of bolt $(\mathrm{MPa})$, and $\mathrm{A}_{\mathrm{s}}$ is the stress area of the bolt $\left(\mathrm{mm}^{2}\right)$.

$\mathrm{F}_{\mathrm{b}, \mathrm{Rd}}=\frac{2.5 \alpha_{b} k_{t} f_{u, c o m p} d_{\text {bolt }} t_{\text {comp }}}{\gamma_{M 2}}$

Where $\alpha_{\mathrm{b}}=1 ; \mathrm{k}_{\mathrm{t}}=1 ; \mathrm{f}_{\mathrm{u}, \mathrm{comp}}$ is the ultimate strength of the component $(\mathrm{MPa}) ; \mathrm{d}_{\text {bolt }}$ for the diameter of the bolt $(\mathrm{mm})$; $\mathrm{t}_{\text {beam }}$ is the thickness of the component $(\mathrm{mm})$. The bearing resistance component is CFS, gusset plate, angle clamp, and bottom flange cleat.

The moment capacity of the middle part $\left(\mathrm{M}_{\mathrm{j}, \mathrm{a}}\right)$ and the side part of the specimen $\left(\mathrm{M}_{\mathrm{j}, \mathrm{b}}\right)$ are affected by 466

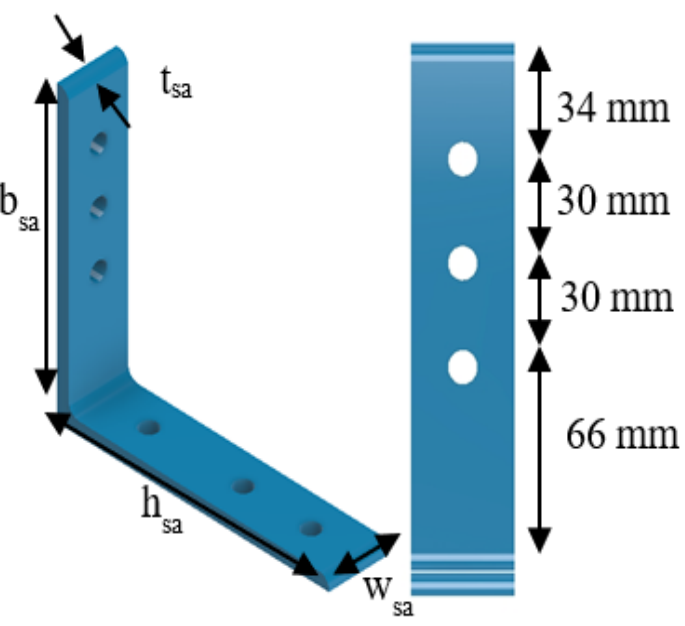

Figure 6 Flange cleat

the minimum value of shear and bearing resistance in each component and the arm's lever. So, the equation is

$\mathrm{M}_{\mathrm{j}, \mathrm{a}}=$ Minimum value between bearing and shear at side gusset plate $\mathrm{x}$ number of bolt $\mathrm{x}$ lever arm $\mathrm{M}_{\mathrm{j}, \mathrm{b}}=$ Minimum value between bearing and shear at middle gusset plate $\mathrm{x}$ number of bolt $\mathrm{x}$ lever of arm

$\mathrm{M}_{\mathrm{j}, \mathrm{gp}}=2 \times \mathrm{M}_{\mathrm{j}, \mathrm{a}}+2 \times \mathrm{M}_{\mathrm{j}, \mathrm{b}}$

The moment capacity with the additional bottom flange cleat is shown in equations 12 and 13.

$\mathrm{M}_{\mathrm{add}}=\mathrm{f}_{\mathrm{y}, \mathrm{sa}} \times \mathrm{w}$

Where $f_{y, s a}$ is the yield strength of bottom flange cleat, and $\mathrm{w}$ is elastic section modulus of bottom flange cleat.

$\mathrm{M}_{\mathrm{total}}=\mathrm{M}_{\mathrm{j}, \mathrm{gp}}+6\left(\mathrm{M}_{\mathrm{add}}\right)$ 


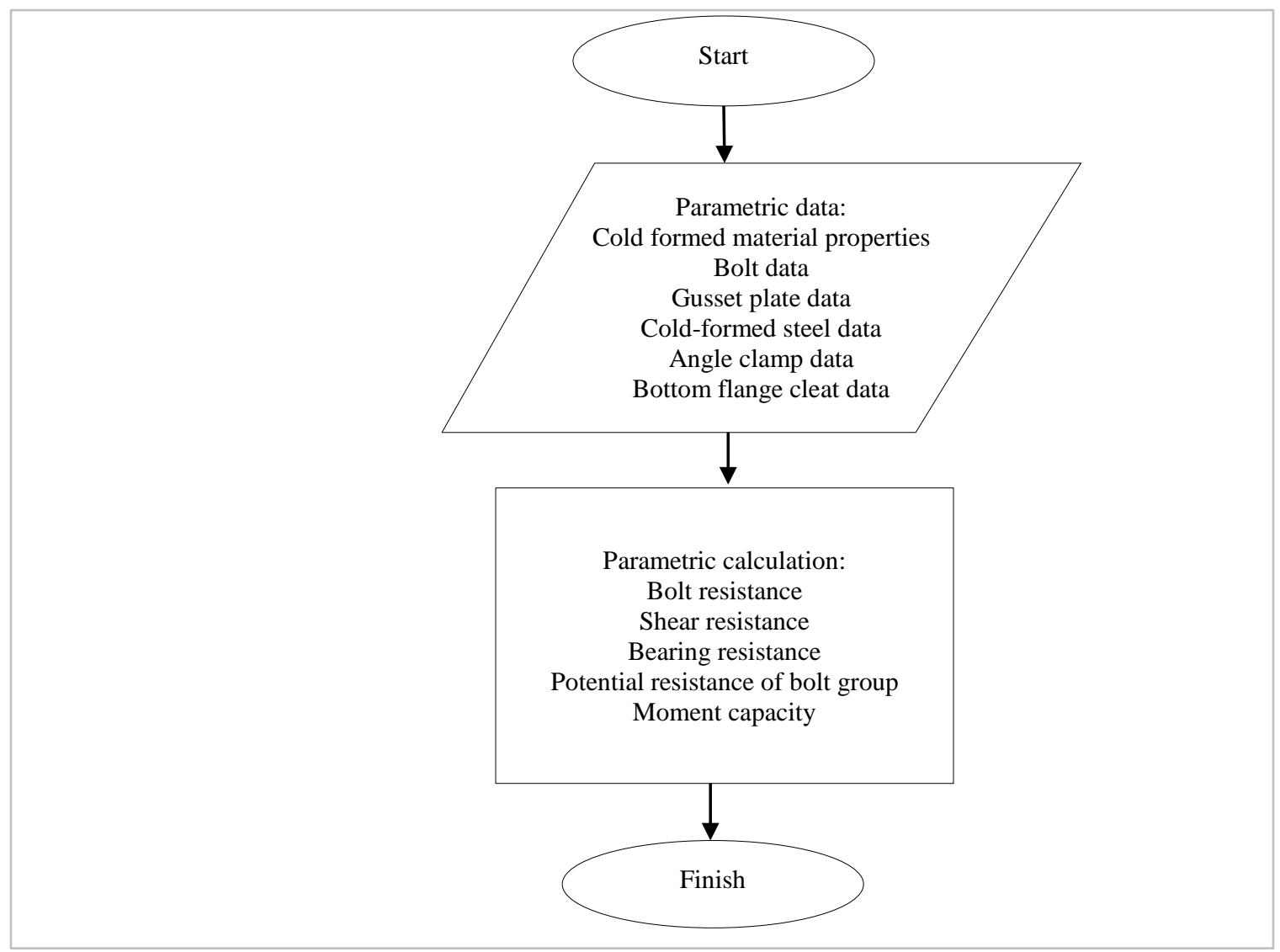

\section{Figure 7 Research flowchart}

\section{Result}

4.1 Range validity

The minimum and maximum edge distance for the M10 bolt are shown in the calculation below. The bolt holes $\left(\mathrm{d}_{0}\right)$ is $11 \mathrm{~mm}$. The validity of the bolt on the gusset plate is shown in Table 1.

$$
\begin{aligned}
\text { Minimum e }_{1} & =1.2 \mathrm{~d}_{0} \\
& =1.2(11) \\
& =13.2 \mathrm{~mm} \\
\text { Maximum e }_{1} & =4(\mathrm{t})+40 \mathrm{~mm} \\
& =4(4)+40 \\
& =56 \mathrm{~mm}
\end{aligned}
$$

The minimum and maximum horizontal spacing between the bolt $\left(\mathrm{p}_{1}\right)$ calculation is based on BS EN 1-8:2005 [20]. The bolt minimum and maximum horizontal spacing are shown in the calculation below.

$$
\begin{aligned}
\text { Minimum } \mathrm{p}_{1} & =2.2 \mathrm{~d}_{0} \\
& =2.2(11) \\
& =24.2 \mathrm{~mm} \\
\text { Maximum } \mathrm{p}_{1} & =14 \mathrm{t} \\
& =14(4) \\
& =56 \mathrm{~mm}
\end{aligned}
$$

For minimum and maximum vertical spacing between bolts is shown in the calculation below.

$$
\begin{aligned}
\text { Minimum } \mathrm{p}_{2} & =2,4 \mathrm{~d}_{0} \\
& =2.4(11) \\
& =26.4 \mathrm{~mm} \\
\text { Maximum } \mathrm{p}_{2} & =14 \mathrm{t} \\
& =14(4) \\
& =56 \mathrm{~mm}
\end{aligned}
$$


Sutanto Muliawan et al.

Table 1 Range validity

\begin{tabular}{|c|c|c|c|c|c|}
\hline Flange cleat & Position & $\begin{array}{c}\text { Min. edge } \\
\text { Spacing }(\mathbf{m m})\end{array}$ & $\begin{array}{c}\text { Spacing } \\
\text { (mm) }\end{array}$ & $\begin{array}{c}\text { Max. edge } \\
\text { spacing }(\mathbf{m m})\end{array}$ & Status \\
\hline \multirow{3}{*}{ Side Gusset Plate } & Side & 13.2 & 20 & 56 & Ok \\
\hline & Horizontal & 24.2 & 50 & 56 & Ok \\
\hline & Vertical & 26.4 & 50 & 56 & $\mathrm{Ok}$ \\
\hline \multirow{3}{*}{$\begin{array}{l}\text { Middle Gusset } \\
\text { Plate }\end{array}$} & Side & 13.2 & 22.5 & 56 & $\mathrm{Ok}$ \\
\hline & Horizontal & 24.2 & 37.5 & 56 & $\mathrm{Ok}$ \\
\hline & Vertical & 26.4 & 37.5 & 56 & Ok \\
\hline
\end{tabular}

\subsection{IJT-01 specimen calculation}

The shear capacity and bearing capacity of the bolt are calculated below.

$$
\begin{aligned}
& \mathrm{F}_{\mathrm{v}, \mathrm{Rd}}=\frac{\alpha_{v} f_{u b} A_{s}}{\gamma_{M 2}}=\frac{0.6 \times 800 \times 58}{1.25}=22.272 \mathrm{kN} \\
& \mathrm{F}_{\mathrm{b}, \mathrm{Rd}, \mathrm{Cfs}}=\frac{2.5 \alpha_{b} k_{t} f_{u, \text { beam }} d_{\text {bolt }} t_{f, \text { beam }}}{\gamma_{M 2}}=\frac{2.5 \times 590 \times 10 \times 2.36}{1.25}=27.848 \mathrm{kN} \\
& \mathrm{F}_{\mathrm{b}, \mathrm{Rd}, \mathrm{gp}}=\frac{2.5 \alpha_{b} k_{t} f_{u, g} d_{\text {bolt }} t_{g}}{\gamma_{M 2}}=\frac{2.5 \times 510 \times 10 \times 4}{1.25}=40.8 \mathrm{kN} \\
& \mathrm{F}_{\mathrm{b}, \mathrm{Rd}, \mathrm{ac}}=\frac{2.5 \alpha_{b} k_{t} f_{u, a c} d_{b o l t} t_{a c}}{\gamma_{M 2}}=\frac{2.5 \times 510 \times 10 \times 4}{1.25}=40.8 \mathrm{kN}
\end{aligned}
$$

Shear and bearing capacity is influenced by the contact plane between plate and bolt. The bearing plane and shear plane for the side gusset plate is shown in Figure 8. The gusset plate calculation at the side position result is shown in Table 2. The gusset plate's moment capacity at the side position is influenced by the lever arm, as shown in Figure 9. The lever arm for the side gusset plate is $35.36 \mathrm{~mm}$, and the moment capacity is calculated below.

Table 2 The side gusset plate calculation result

\begin{tabular}{clllll}
\hline & Component & Bearing plane & Shear plane & $\begin{array}{l}\text { Bearing capacity } \\
(\mathbf{k N})\end{array}$ & $\begin{array}{l}\text { Shear capacity } \\
(\mathbf{k N})\end{array}$ \\
\hline \multirow{3}{*}{$\begin{array}{c}\text { Side Gusset } \\
\text { Plate }\end{array}$} & Bolt & - & 2 & - & 44.544 \\
& Cold-formed Steel & 1 & - & 27.848 & - \\
& Gusset Plate & 1 & - & 40.8 & - \\
& Angle Clamp & 1 & - & 40.8 & - \\
\hline
\end{tabular}

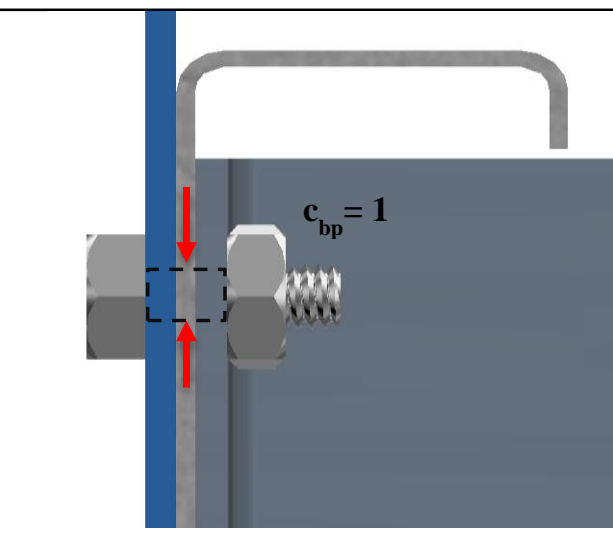

Bearing resistance plane

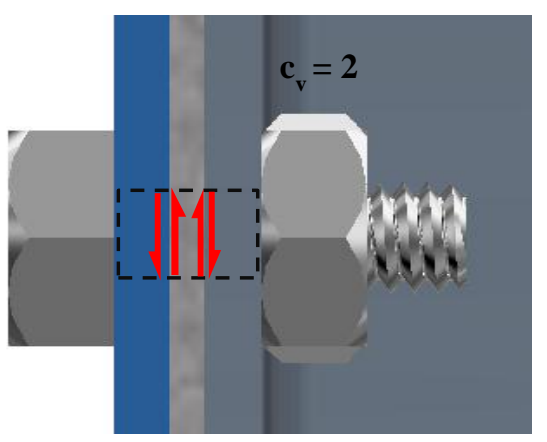

Shear resistance plane

Figure 8 The bearing and shear plane on the side gusset plate 


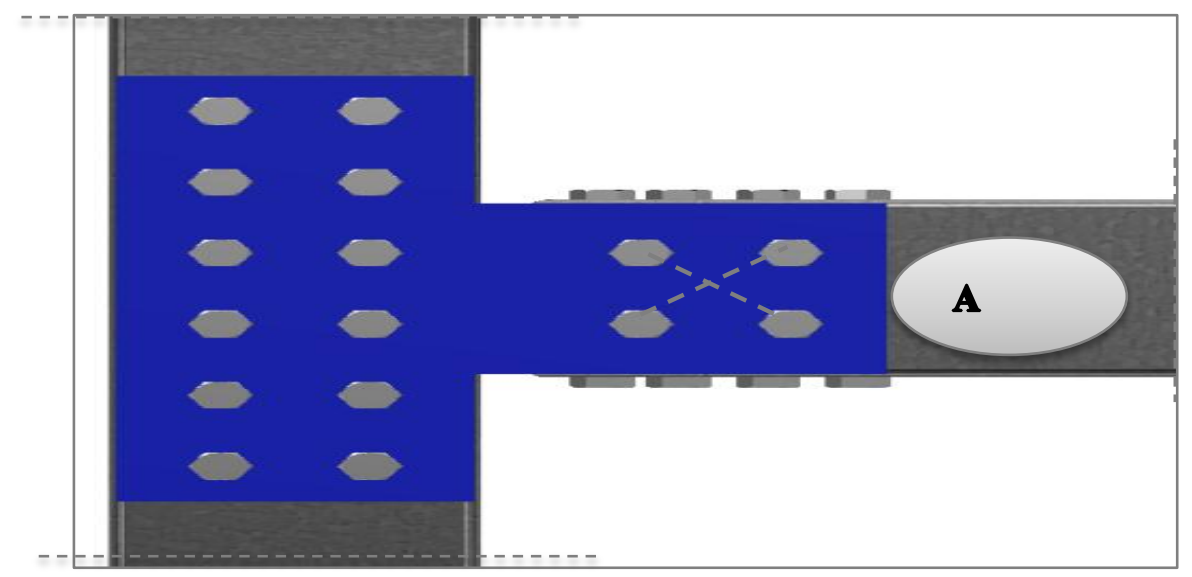

Figure 9 Lever of arm for side gusset plate

$\mathrm{M}_{\mathrm{j}, \mathrm{a}}=4 \times 35.36 \times 27.85=3.938 \mathrm{kNm}$

The bearing plane and shear plane for the middle gusset plate is shown in Figure 10. The middle gusset plate calculation result is shown in Table 3.
The moment capacity of the gusset plate at middle position is influenced by the lever arm in Figure 11. The lever arm for the middle gusset plate is 28.29 $\mathrm{mm}$, and the moment capacity is calculated below.

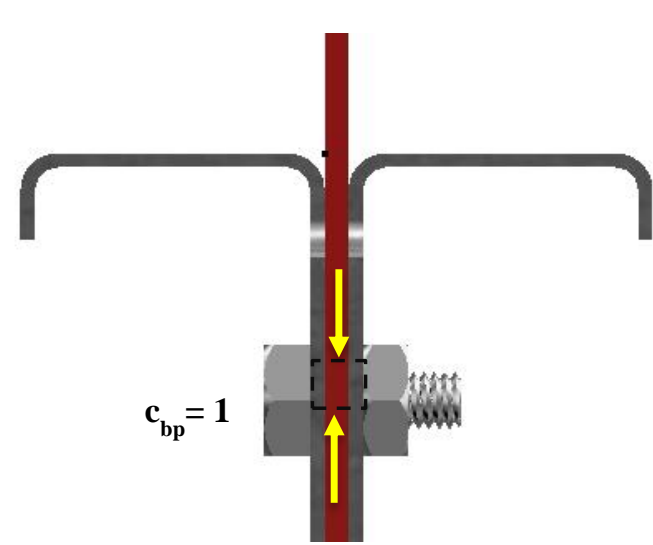

Bearing resistance plane

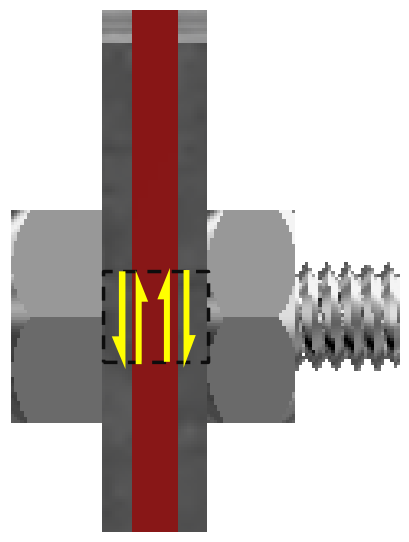

Shear resistance plane

Figure 10 The Bearing and shear plane on the middle gusset plate

Table 3 The middle gusset plate calculation result

\begin{tabular}{clllll}
\hline & Component & Bearing plane & Shear plane & $\begin{array}{l}\text { Bearing capacity } \\
(\mathbf{k N})\end{array}$ & $\begin{array}{l}\text { Shear capacity } \\
(\mathbf{k N})\end{array}$ \\
\hline \multirow{2}{*}{$\begin{array}{c}\text { Middle Gusset } \\
\text { Plate }\end{array}$} & Bolt & - & 2 & - & 44.544 \\
& Cold-formed Steel & 2 & - & 55.7 & \\
\hline
\end{tabular}


Sutanto Muliawan et al.

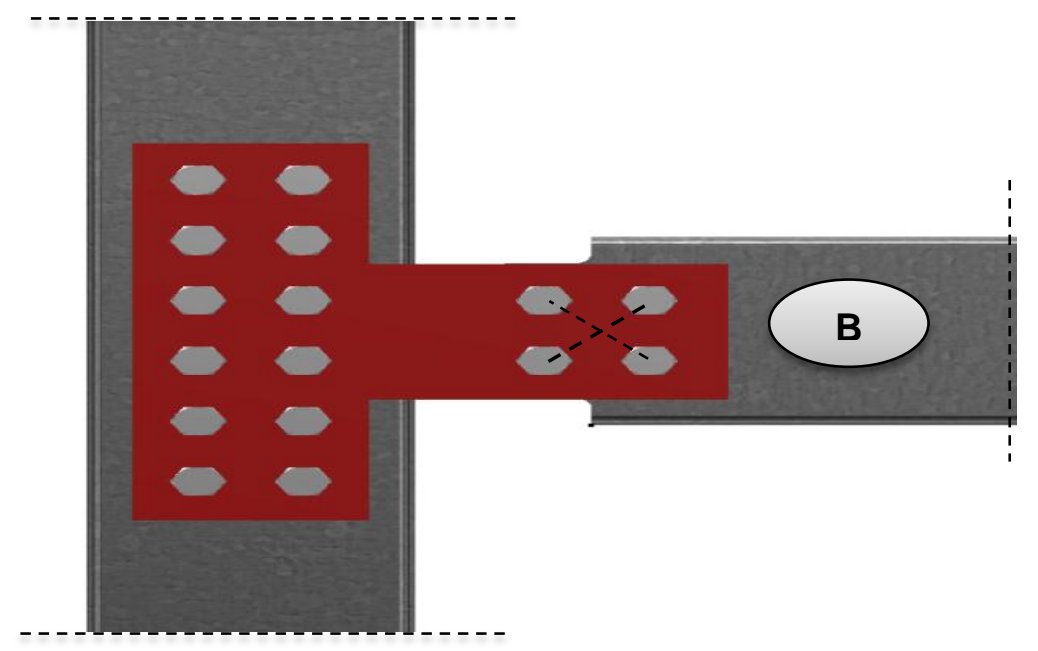

Figure 11 Lever of arm for middle gusset plate

$\mathrm{M}_{\mathrm{j}, \mathrm{b}}=4 \times 28.29 \times 40.8=4.616 \mathrm{kNm}$

Total moment capacity of the connection for IJT-01 is:

$\mathrm{M}_{\mathrm{j}}=2 \mathrm{M}_{\mathrm{j}, \mathrm{A}}+2 \mathrm{M}_{\mathrm{j}, \mathrm{B}}=2 \times 3.938+2 \times 4.616=17.11 \mathrm{kNm}$

The final result for IJT-01 is $17.11 \mathrm{kNm}$, and it is matched to the previous study [10].

\subsection{IJT-02 specimen calculation}

The cold-formed steel, gusset plate, and angle clamp in IJT-02 are typical of IJT-01. Therefore, the moment capacity of the gusset plate for IJT-02 is similar to IJT-01. As shown in Figure 12, the bottom flange cleat could increase the moment resistance because of the additional bending moment produced from the angle section. The calculation is shown below.

$\mathrm{M}_{\mathrm{add}}=\mathrm{f}_{\mathrm{y}, \mathrm{sa}} \times \mathrm{w}=355 \mathrm{MPa} \times\left(1 / 6 \times 50^{2} \times 7\right) \mathrm{mm}^{4}=1,04$ $\mathrm{kNm}$

Total moment capacity of the connection for IJT-02 is

$\mathrm{Mj}=17.11+6(1.04)=23.32 \mathrm{kNm}$

The moment capacity comparison between IJT-01 and IJT-02 is shown in Table 4. The moment capacity of connection has improved when the bottom flange cleat is added.

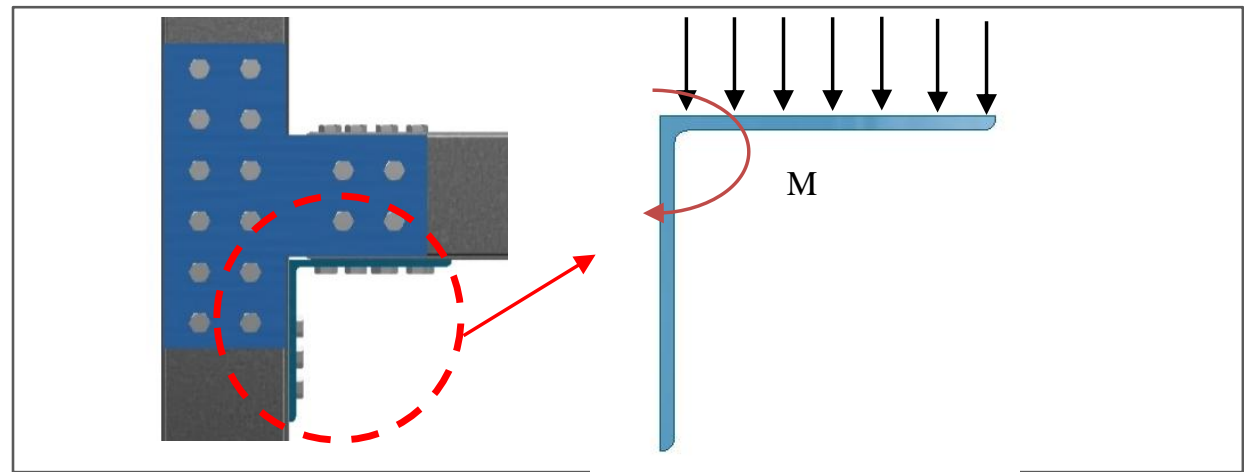

Figure 12 Bottom flange cleat additional moment

Table 4 Moment capacity comparison 


\section{Discussion}

According to Table 2, the gusset plate at the side position is possible to fail at bearing failure at the beam bolt hole. The bolts' bearing resistance $(27.848$ $\mathrm{kNm})$ at cold-formed steel is very small rather than the gusset plate or the angle clamp. Bolt shear capacity has a high value rather than the bearing capacity of cold-formed steel, gusset plate, and angle clamp in the specimen's side part. Subsequently, it could be predicted that the connection would not fail because of shear. At the middle part of the specimen, the bolt shear capacity is high rather than the gusset plate's bearing capacity. There is a possibility that gusset plate failure will occur in the middle part because the gusset plate's bearing capacity is very low compared with cold-formed or bolt shear capacity.

The moment capacity for IJT-01 is $17.11 \mathrm{kNm}$, and the bearing resistance is less than shear resistance. The moment capacity of IJT $02(23.32 \mathrm{kNm})$ is more than the IJT $01(17.11 \mathrm{kNm})$. This proves that the seat angle section could increase the joint capacity. In this paper, the calculation procedure was proposed, and the elastic behaviour was assumed according to component method (BS EN 1993-1-8 and BS EN 1993-1-3).

\section{Conclusion and future work}

Based on this research, it is clear that the two specimens, the bolt shear capacity has a high value rather than the bearing capacity. It caused by the grade of the bolt is high enough to resist the shear failure. The bearing resistance is influenced by the other connected components, such as the gusset plate, cold-formed steel, and angle clamp for the side gusset plate. The weakest part on the side connection is at the CFS because the bearing plane for CFS is 1 . The weakest part of the middle connection is at the gusset plate because the CFS has more bearing planes than the gusset plate bearing plane. The moment capacity of the connection is the results from the calculation of each component of the connection. By installing the flange cleat, the connection capacity is increase. The effect of bottom flange cleat installation has improved the connection moment capacity from $17.11 \mathrm{kNm}$ to $23.2 \mathrm{kNm}$. The future work to be recommended is to add one more flange cleat at the top of the connection between the cold-formed steel reinforced slab and column panel. It is recommended to make a sub-assemblage frame specimen of the connection.

\section{Acknowledgment}

None.

Conflicts of interest

The authors have no conflicts of interest to declare.

\section{References}

[1] Yu WW, LaBoube RA, Chen H. Cold-formed steel design. Hoboken: Wiley; 2010.

[2] Saggaff A, Firdaus M, Tahir MM, Ngian SP, Siang TC, Aminuddin KM, Salih MN. Experimental study on composite connection with double lipped csections. In IOP conference series: materials science and engineering 2020 (pp. 1-9). IOP Publishing.

[3] Amsyar F, Siang TC, Sulaiman A, Khun MC. Numerical and experimental study of semi-rigid beamto-column composite connections in cold-formed steel. In AIP conference proceedings 2020 (p. 020011). AIP Publishing LLC.

[4] Sulaiman A, Salleh NM, Sukardi N, Siang TC, Saggaff A. Experimental evaluation of composite beam-to-column joint using cold-formed steel sections. In IOP conference series: materials science and engineering 2019 (pp.1-13). IOP Publishing.

[5] Firdaus M, Saggaff A, Tahir MM, Aghlara R, Sulaiman A, Aminuddin K, et al. Influence of seat angles on the behaviour of cold-formed steel concrete composite joints. Journal of Constructional Steel Research. 2020; 173:106246.

[6] Aminuddin K, Saggaff A, Tahir MM, Ngian SP, Sulaiman A, Firdaus M, et al. Analytical and experimental investigation on slip-in gusset plate connection for double c-channel sections of coldformed steel. The Open Civil Engineering Journal. 2019; 13(1):210-7.

[7] Aminuddin KM, Saggaff A, Tahir MM, Ngian SP, Sulaiman A, Firdaus M, et al. Behaviour of rectangular gusset plate with angle cleat connections for cold-formed steel section. In IOP conference series: materials science and engineering 2020 (pp. 18). IOP Publishing.

[8] Firdaus M, Saggaff A, Tahir MM, Aminuddin KM, Ngian SP, Siang TC, et al. Behavior of partial strength of beam-to-column connection with gusset plate for cold-formed steel sections. ASEAN Engineering Journal. 2020; 10(2).

[9] Hanisha CS, Kishore IS. Experimental and finite element analysis of cold formed steel beam-column joint. Materials Today: Proceedings. 2020; 33:480-3.

[10] Muliawan S, Saggaff A, Mahmood T, Firdaus M, Aminuddin KM. Loading capacity calculation of integrated precast slab and column panel using coldformed steel. In journal of physics: conference series 2021 (pp. 1-7). IOP Publishing.

[11] Armo AA, Saggaff A, Tahir MM, Ngian SP, Sulaiman A, Salih MN. Behaviour of rebar shear connector in a push test for composite beam with cold-formed steel section. In IOP conference series: materials science and engineering 2019 (pp.1-10). IOP Publishing. 
[12] Salih MN, Tahir MM, Mohammad S, Ahmad Y, Sulaiman A, Shek PN, et al. Experimental study on flexural behaviour of partially encased cold-formed steel composite beams using rebar as shear connector. In IOP conference series: materials science and engineering 2019 (pp. 1-8). IOP Publishing.

[13] Khadavi MM, Salih MN, SA AA, Shek PN. Behaviour of composite beam arranged as boxed-section with cchannel of cold-formed steel of lipped section.

[14] Lawan MM, Shek PN, Tahir MM. Flexural performance of cold-formed steel section in a composite beam system. In IOP conference series: materials science and engineering 2020 (pp. 1-12). IOP Publishing.

[15] Salih MN, Tahir MM, Mohammad S, Ahmad Y, Shek PN, Abraham A, et al. Bending experiment on a novel configuration of composite system using rebar as shear connectors with partially encased cold-formed steel built-up beams. Materials Today: Proceedings. 2021; 39:999-1005.

[16] Firdaus M, Saggaff A, Tahir M, Ngian SP, Sulaiman A, Salih MN. Experimental and analytical study on composite connection with cold-formed steel of double channel sections. In IOP conference series: materials science and engineering 2019 (p. 012044). IOP Publishing.

[17] Firdaus M, Saggaff A, Tahir MM, Ngian SP, Sulaiman A. Prediction of moment resistance of steel connection with macro excel using eurocode standard. In journal of physics: conference series 2019 (pp. 1-10). IOP Publishing.

[18] Lawan MM, Shek PN, Tahir MM. Can cold-formed steel section be use as a sustainable structural member in building and Civil engineering constructions? a mini review. In IOP conference series: materials science and engineering 2020 (pp. 1-13). IOP Publishing.

[19] Qiao W, Yan X, Zhu R, Wang F, Wang D. Flexural properties of new cold-formed thin-walled steel and concrete composite slabs. Journal of Building Engineering. 2020; 31:101441.

[20] Standard B. Eurocode 3-design of steel structures-. BS EN 1993-1. 2006; 1:2005.

[21] https://shop.bsigroup.com/ProductDetail?pid=000000 000030283899. Accessed 26 October 2020.

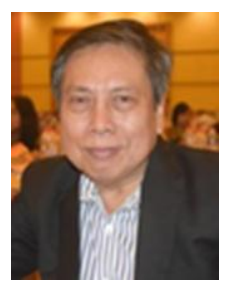

Sutanto Muliawan is $\mathrm{PhD}$ student of Civil Engineering, Faculty of Engineering, Sriwijaya University. $\mathrm{He}$ is lecturer in the Civil Engineering Department, Faculty of Engineering, Sriwijaya University, Indonesia. His research focuses on Foam Concrete, Cold-Formed Steel, and Light-weight

Construction

Email: sutantomuliawan@yahoo.com

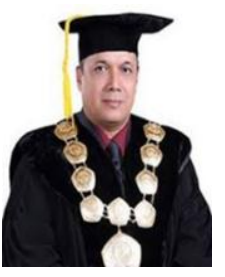

Anis Saggaff is a Professor in the Civil Engineering Department, Faculty of Engineering, Sriwijaya University, Indonesia. He received a Doktor in Civil Engineering from University Teknologi Malaysia. He is Rector of Sriwijaya University. His research focuses on Geopolymer Concrete, Nanomaterial Concrete, Lightweight Concrete, Reactive Powder Concrete, Self Compacting Concrete, Cold-Formed Steel, and Light-weight Construction.

Email: anissaggaf@yahoo.com

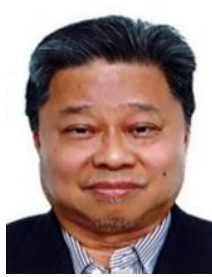

Mahmood Md Tahir is a lecturer in Institute for Smart Infrastructure ad Innovative Construction (ISIIC), Construction Research Centre (CRC), School of Civil Engineering, Universiti Teknologi Malaysia, Johor Bahru, Malaysia. His research focuses on Lightweight Concrete, Cold-Formed Steel, and Light-weight Construction.

Email: mahmoodtahir@utm.my

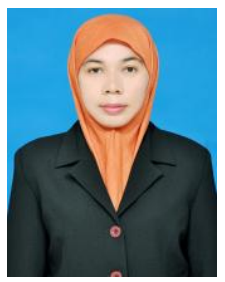

Saloma is a lecturer in the Civil Engineering Department, Faculty of Engineering, Sriwijaya University, Indonesia. She received a Doktor in Civil Engineering from Institut Teknologi Bandung in 2014. She is Head of Graduate of Civil Engineering at Sriwijaya University. Her research focuses on Geopolymer Concrete, Nanomaterial Concrete, Lightweight Concrete, Reactive Powder Concrete, SelfCompacting Concrete, Cold-Formed Steel, and Lightweight Construction

Email: salomaunsri@gmail.com

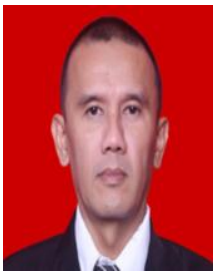

Muhammad Firdaus is a lecturer in Civil Engineering Department, Faculty of Engineering, Universitas Persatuan Guru Republik Indonesia, Palembang, Indonesia. He received a Doktor in Civil Engineering from Sriwijaya University in 2019. His research focuses on Lightweight Concrete, Self Compacting Concrete, Cold-Formed Steel, and Lightweight Construction.

Email: firdaus@univpgri-palembang.ac.id

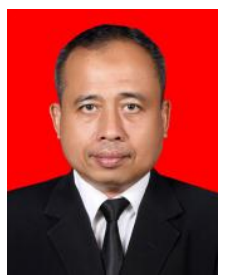

KM Aminuddin is a lecturer in the Civil Engineering Department, Faculty of Engineering, Sriwijaya University, Indonesia. He received a Doktor in Civil Engineering from Sriwijaya University in 2019. His research focuses on Lightweight Concrete, Cold-Formed Steel, and Light-weight

Construction.

Email: kmaminuddin@ft.unsri.ac.id 